\title{
Pathogenicity Assay and Molecular Identification of Fungi and Bacteria Associated with Diseases of Tomato in Malaysia
}

\author{
Tavga Sulaiman Rashid ${ }^{1,2 *}$, Kamaruzaman Sijam¹, Hayman Kakakhan Awla1,2, \\ Halimi Mohd Saud1, Jugah Kadir' ${ }^{1}$ \\ ${ }^{1}$ Department of Plant Protection, Faculty of Agriculture, University Putra Malaysia, \\ Serdang, Malaysia \\ ${ }^{2}$ Department of Plant Protection, Faculty of Agriculture, University of Salahaddin, Erbil, Iraq \\ Email: *tavga2020@yahoo.com
}

Received 27 March 2016; accepted 25 April 2016; published 28 April 2016

Copyright (C) 2016 by authors and Scientific Research Publishing Inc.

This work is licensed under the Creative Commons Attribution International License (CC BY). http://creativecommons.org/licenses/by/4.0/

cc) (i)

\section{Abstract}

This study was conducted in order to determine the fungi and bacteria associated with tomato plants at Cameron Highlands Malaysia. The fungi which have been isolated and detected from tomato plants were: Fusarium oxysporum, F. solani, F. acuminatum, Rhizoctonia solani, Colletotrichum boninense, $C$. acutatum and Phoma destructiva. The bacteria which have been isolated and detected from tomato plants were: Ralstonia solanacearum, Xanthomonas vesicatoria, $X$. gardneri and Pseudomonas syringae. While the most pathogenic fungi were $C$. boninense, $P$. destructive and $F$. oxysporum with the disease incidence $(89.6 \%, 86.6 \%, 85.6 \%)$ respectively, the most pathogenic bacteria were $X$. vesicatoria and $R$. solanacearum with the disease incidence $(96.6 \%$ and $87.6 \%)$ respectively.

\section{Keywords}

Lycopersicon esculentum, Pathogen Isolation and Molecular Identification

\section{Introduction}

An estimated 124.5 million tonnes of tomatoes (Lycopersicon esculentum Mill.) are produced annually through-

*Corresponding author.

How to cite this paper: Rashid, T.S., Sijam, K., Awla, H.K., Saud, H.M. and Kadir, J. (2016) Pathogenicity Assay and Molecular Identification of Fungi and Bacteria Associated with Diseases of Tomato in Malaysia. American Journal of Plant Sciences, 7, 949-957. http://dx.doi.org/10.4236/ajps.2016.76090 
out the world, making one of the ten most important fruits and vegetables in modern history [1]. Production of tomatoes tends to be more successful in highland areas in Malaysia, mainly due to the milder temperatures there. Hence, Cameron Highlands is a popular location for large-scale tomato cultivation. There are still a large number of fungal and bacterial diseases that make tomato production challenging in various parts of the world despite decades of conventional breeding and selection. Presently, tomato is vulnerable to more than 200 diseases. Yield losses to diseases can run as high as $70 \%$ to $95 \%$. As extensive cultivation of tomatoes continues, diseases caused by bacteria, soil borne fungi, seed borne and foliar fungi have also increased even continuous improvement in strain variety [2].

In greenhouse and open field production, bacterial diseases are a serious problem. In the warm and temperate regions of the world, five major bacterial pathogens are responsible for damages to the roots, stems, twigs, leaflets, leaves, buds, flowers and fruits. These include Pseudomonas syringae pv. tomato, the causal agent of bacterial speck, Xanthomonas vesicatoria, the causal agent of bacterial spot, Clavibacter michiganensis subsp., Michiganensis, the causal agent of bacterial canker, Pseudomonas corrugate, the causal agent of bacterial pith necrosis and Ralstonia solanacearum, the causal agent of bacterial wilt [3]. In Malaysia, economic crops and vegetables such as tomatoes, chillies and groundnuts bacterial are plagued by wilt, a serious bacterial disease, caused by $R$. solanacearum [4] [5].

The most severe fungal diseases that threaten tomato yields and cause worldwide economic losses are the wilts caused by Fusarium oxysporum f. sp. lycopersici, root rot caused by Fusarium solani, damping off caused by Rhizoctonia solani and root rot and damping-off caused by several Pythium species [6]. The most economically damaging phytopathogenic fungi are Colletotrichum sp., which causes anthracnose, and Phoma destructiva, which causes Phoma rot [7].

Bacterial wilt (R. solanacearum), bacterial spot (X. vesicatoria), early blight (Alternaria solani), anthracnose (Colletotrichum spp.), Sclerotium wilt (Sclerotium rolfsii), damping off ( $R$. solani), tomato wilt (F. oxysporum) and viruses such as tomato mosaic virus have been reported on tomato in Malaysia [5] [8].

The present study was initiated to isolate and identify tomato pathogens in Cameron Highlands, Malaysia via molecular identification and evaluate the pathogenicity and virulence variability of pathogenic isolates.

\section{Materials and Methods}

\subsection{Pathogens Isolation}

Leaf, stem, root and fruit samples of tomato plants with disease symptoms were gathered from various tomato fields in Cameron Highlands, Pahang, Malaysia. Five $\mathrm{mm}^{2}$ segments were taken from the edge of the different samples in order to isolate the causative fungal and bacterial pathogens. One\% $\mathrm{NaOCl}$ was then used to surface sterilize the specimens for two minutes. After sterilization, sterilized distilled water was used to rinse the samples twice and then dried on sterilized filter papers.

For fungi isolation specimens were placed into petri dishes with Potato Dextrose Agar (PDA) and kept in an incubator at $28^{\circ} \mathrm{C}$ for 3 to 6 days to let the fungi grow. After that, the samples were monitored under a stereomicroscope and conidia or single hyphae were moved to PDA plates with a needle and kept in an incubator until the fungi developed. The obtained pure cultures were used in this study.

For bacteria isolation specimens were moved into small test tubes and soaked in $2 \mathrm{~mL}$ of sterilized distilled water for an hour. The tubes were stirred in a vortex mixer to obtain turbid bacterial suspensions. Loopfuls of the resulting aqueous suspension were streaked onto Nutrient Agar (NA) and incubated at $30^{\circ} \mathrm{C}$ for 2 days. Different colonies were again streaked onto NA plates and this process was repeated until purified bacterial cultures were obtained with homogeneity colony morphology.

\subsection{DNA Extraction and Sequence Analyses}

\subsubsection{DNA Extraction and Molecular Identification of Fungal Isolates}

Fungal mycelial mats were put into $1.5 \mathrm{~mL}$ micro tubes and centrifuged at $3000 \mathrm{rpm}$ for 5 minutes at $4^{\circ} \mathrm{C}$. The supernatants were then carefully removed. DNA extraction was performed with the 3\% SDS method [9].

The ITS (including, ITS1 and ITS2, 5.8S rDNA) region was selected to characterise isolates using universal primers [10]. 


\subsubsection{DNA Extraction and Molecular Identification of Bacterial Isolates}

For 24 hours at $30^{\circ} \mathrm{C}$, each bacteria isolate was cultivated in a nutrient broth. A commercial genomic DNA purification kit was used to extract the total genomic DNA from all the isolates. The 8F forward primer (-5-GTG ACACGTACACGT-3-) and 1492R reverse primer (-5-ATCGCACGTACACGT-3-) were used to amplify he 16S RNA gene. A $25 \mu$ reaction mixture containing 10 ng of genomic DNA, $2.5 \mu$ of 10X PCR buffer, $2.5 \mu$ of $\mathrm{MgCl}_{2}, 200 \mu \mathrm{M}$ of dNTP mix, $10 \mathrm{p}$ mol each of the primers and 1 unit of Taq DNA polymerase was used for the PCR reaction. The initial denaturation temperature was set at $95^{\circ} \mathrm{C}$ for 5 minutes, followed by 30 cycles of denaturation for 1 minute, annealing at $55^{\circ} \mathrm{C}$ for 1 minute and extension at $72^{\circ} \mathrm{C}$ for 2 minutes. A final extension was carried out at $72^{\circ} \mathrm{C}$ for 5 minutes [11].

\subsection{Pathogenicity Assays}

For bacteria inoculation preparation, the bacteria were streaked on the NA medium and incubated for 48 hours at $28^{\circ} \mathrm{C}$. NA plate cultures in sterile distilled water were prepared by suspending the growth from 48 hours. Tween 20 , as a surfactant, was combined with bacteria suspensions containing about $10^{8} \mathrm{cfu} / \mathrm{ml}$ and for a final concentration of $0.02 \%(\mathrm{v} / \mathrm{v})$.

For fungi inoculation preparation, conidial suspension was readied by sampling conidia from seven days old fungal culture isolates grown on PDA using $5-10 \mathrm{~mL}$ sterilized distilled water. A sterile spatula was used to scrub the surface of the fungus plates. A haemocytometer was used to adjust the concentration of the conidia suspension to $3 \times 10^{5}$ conidia/mL and tween 20 was added as a surfactant for a final concentration of $0.02 \%$ $(\mathrm{v} / \mathrm{v})$.

The tomato seeds (cultivar Baccarat 322) were disinfected with 50\% Benomyl fungicide and streptomycin for 2 hours prior to sowing. Disinfected seeds were hand sown in 231-hole plastic plug trays and placed in the glasshouse under natural daylight. They were also watered daily. Two seedlings were taken from the plug trays and moved to pots, four replications for each treatment.

Four-week old tomato plants were sprayed with a conidia suspension containing $3 \times 10^{5}$ conidia/mL (15 $\mathrm{mL} / \mathrm{pot})$ and the bacterial inoculum $\left(10^{8} \mathrm{cfu} / \mathrm{ml}\right)$ in distilled water. To increase infection, roots of test plants were wounded with a sharp scalpel by stabbing the soil several times and then pouring of $15 \mathrm{ml}$ of bacterial inoculum and conidia suspension onto surface of the soil. Plants that were not inoculated were sprayed with distilled water that had similar concentration of tween 20. The plants were covered with black plastic bags for 24 hours after inoculation. The plastic bags were removed after $24 \mathrm{~h}$ and plants watered daily. Disease incidence and severity [12] were measured seven days after inoculation.

Small sections $(1 \times 1 \mathrm{~cm})$ of diseased leaves, stems or roots were surface sterilized with $10 \%$ of sodium hypochlorite for 1 - 2 minutes and rinsed three times with sterile distilled water for fungus and bacteria isolation,. The segments were then cultured on PDA or NA culture mediums. To prove that Koch's postulates were true, the final colony and conidia characteristics were analysed to confirm that the isolated fungus or bacteria were the same with what had been used for the pathogenicity test.

\subsection{Statistical Analyses}

SAS software version 9.2 was used to perform the Analysis of Variance (ANOVA) (Cary, NC: SAS Institute Inc. 2011). LSD test at the 0.05 probability level was used to determine the statistical differences among the different bacteria and fungi isolates.

\section{Results}

\subsection{Bacterial and Fungal Isolates}

From different parts of the tomato plants, at total of 28 fungal entities with seven different morphologies were molecularly identified. Also identified were four different pathogenic species of bacteria from 42 isolates (Table $1)$.

\subsection{Molecular Identification and Phylogenetic Analysis}

The amplification of the 16S and ITS genes were clearly defined in the results. The identification were confirmed 
Table 1. Bacterial and fungal isolates with their genebank accession numbers, disease severity scores and ranges.

\begin{tabular}{ccccccc}
\hline No. & Pathogens & $\begin{array}{c}\text { Genebank } \\
\text { Accession } \\
\text { number }\end{array}$ & Isolate name & Diseases caused by & $\begin{array}{c}\text { Disease } \\
\text { severity } \\
\text { score }\end{array}$ & $\begin{array}{c}\text { Disease } \\
\text { severity } \\
\text { range }\end{array}$ \\
\hline 1 & Pseudomonas syringae pv. tomato & KT783474 & UPMTPs & Tomato bacterial speck & 5 & $82.3 \pm 0.3 \mathrm{e}$ \\
2 & Ralstonia solanacearum & KT783476 & UPMTRs & Tomato bacterial wilt & 5 & $87.6 \pm 0.3 \mathrm{c}$ \\
3 & Kanthomonas vesicatoria & KU661975 & UPMTXv & Tomato bacterial leaf spot & 5 & $96.6 \pm 0.5 \mathrm{a}$ \\
4 & Xantho monasgardneri & KP765608 & UPMXo1 & Tomato bacterial leaf spot & 4 & $71.3 \pm 0.6 \mathrm{f}$ \\
5 & Fusarium oxysporum & KM039054 & UPMT48 & Tomato wilt & 5 & $85.6 \pm 0.3 \mathrm{~d}$ \\
6 & Fusarium solani & KM039055 & UPMT44 & Tomato foot rot & 3 & $55 \pm 0.5 \mathrm{i}$ \\
7 & Fusarium acuminatum & KM039056 & UPMT012 & Tomato fruit rot & 2 & $40 \pm 0.5 \mathrm{j}$ \\
8 & Rhizoctonia solani & KP262071 & UUPMT34 & Damping off & 3 & $68.3 \pm 0.3 \mathrm{~g}$ \\
9 & Phoma destructiva & KR559677 & UPMT08 & Phoma blight & 5 & $86.6 \pm 0.3 \mathrm{~b}$ \\
10 & Colletotrichum boninense & KM039057 & UPMTS20 & Anthracnose & 5 & $89.6 \pm 0.3 \mathrm{~cd}$ \\
11 & Colletotrichum acutatum & KT215296 & UPMT02 & Fruit rot anthracnose & 4 & $64.3 \pm 0.3 \mathrm{~h}$ \\
\hline
\end{tabular}

with PCR amplification with primers 16S of all bacteria isolates from the infected tomato plants produced 1400 - 1500 bp amplicon. Consequently, 550 - 650 bp amplicon were produced from PCR amplification with ITS primers of all fungi isolates isolated from the infected tomato plants which confirmed fungi identification.

All bacteria and fungi we obtained clustered together with 95\% - 99\% relationship with other reference sequences from the gene bank based on the phylogenetic analysis (Figure 1 and Figure 2).

\subsection{Pathogenesis Determination}

The pathogenicity studies showed that all the fungus ( $R$. solani, F. solani, F. oxysporum, P. destructiva, $C$. boninense and $C$. acutatum) and bacteria ( $R$. solanacearum, $P$. syringae, $X$. vesicatoria and $X$. gardneri) under investigation had obvious effects on the growth of tomato seedlings. After two weeks, un-inoculated seedlings were free of typical disease symptoms while the seedlings inoculated with the pathogens exhibited them. Fungal isolates were re-isolated from the infected plants but not from the control plants to confirm Koch's postulate. Percent disease severity (PDS) was significantly different among the bacterial and fungal isolates as per the results of indicated by ANOVA (Table 1 and Figure 3).

\subsection{Symptom Development on Inoculated Seedlings}

5 - 7 days after inoculation, typical disease symptoms were observed on the tomato plants. Small circular spots, which coalesced to form large, irregular lesions on the leaves, were the visible external symptoms of infection by $X$. vesicatoria. These lesions eventually turned dark brown and were water-soaked approximately $3 \mathrm{~mm}$ in diameter on the leaves.

The typical symptoms externalized by $X$. gardneri were small circular to angular water-soaked brown lesions. These lesions eventually dried up to form light brown, regular or irregular necrotic lesions and chlorosis soon appeared.

Symptoms caused by $P$. syringae pv. tomato initially started with brown necrotic specks that turned black and encircled with yellow coronas on the leaves and stem.

The symptoms of tomato plants inoculated with $R$. solanacearum started with wilting of the youngest leaves with no foliar yellowing. When the stems of the affected plants were cut and submerged in water, a whitish ooze was evident and the longitudinal sections showed a brown discolouration.

The tomato plants inoculated with fungi exhibited other types of symptoms. C. boninense produced small, circular and immersed lesions on the leaves. These lesions eventually turned light brown with orange spore masses in a dark centre. On the other hand, C. acutatum triggered dark, sunken and circular lesion on the leaves. 
F. acuminatum only showed symptoms of yellowing leaves while symptoms caused by $F$. oxysporum started with yellowing and wilting of the lower leaves followed by the vascular turning to dark brown and being discoloured. F. solani inflicted interveinal chlorosis and bleaching of the lamina on the leaves and taproots while reddish brown cortical lesions and vascular discoloration were apparent above and below the lesions.

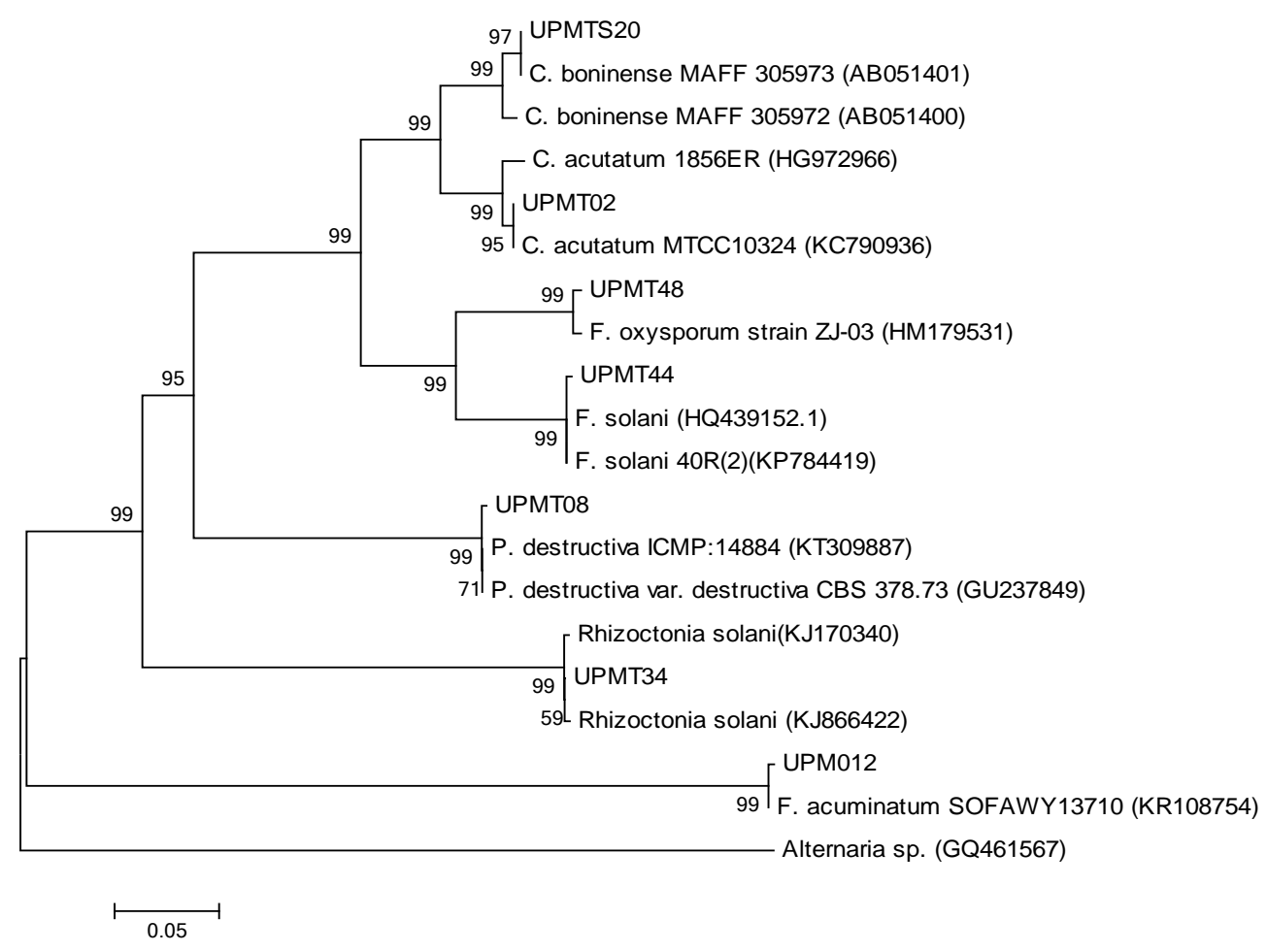

Figure 1. Phylogenetic tree constructed by the neighbor-joining method showing the phylogenetic relationships of all isolated fungi compared with the reference sequences from gene bank.

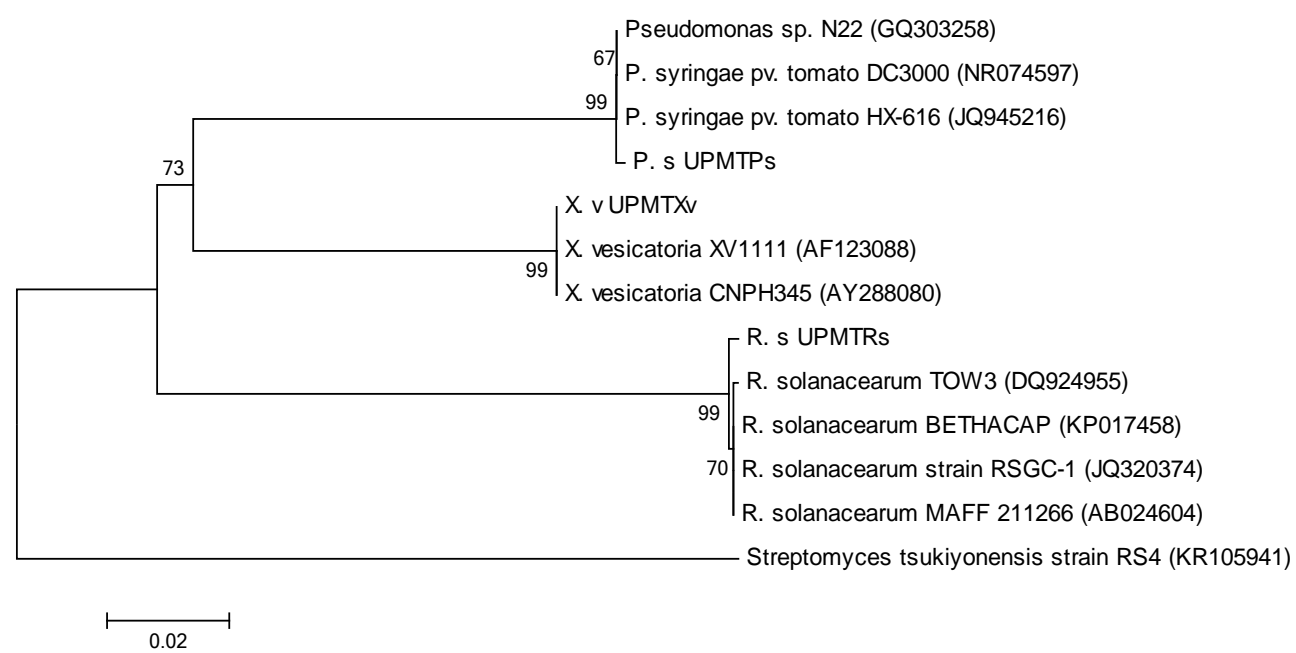

Figure 2. Phylogenetic tree constructed by the neighbour-joining method showing the phylogenetic relationships of all isolated bacteria compared with the reference sequences from gene bank. Based on MEGA 6, neighbour joining was utilised on the phylogenetic tree. On tree nodes, bootstrap values obtained from 500 replications were indicated as percentages. The tree was drawn according to scale with the lengths of the branches in the same units as those of the evolutionary distances used to refer to the phylogenetic tree. The p-distance method was used to compute the evolutionary distances and is in the units of the number of base differences per site. 
The symptoms of $P$. destructiva can be identified by small black lesions that appear on leaf surfaces, which are irregular to round in shape, slightly sunken and zonate, stem lesions that elongate and similar to insect punctures or stem scar cracks and all foliar spots develop obvious black pycnidia with hand lens. The symptoms caused by $R$. solani were the hypocotyl, stem cankers and roots turning brown (Figure 4).

The pathogenicity tests on tomato seedlings indicated that $X$. vesicatoria and $C$. boninense were highly pathogenic followed by $P$. destructiva, $R$. solanacearum and $F$. oxysporum while $F$. acuminatum and $F$. solani had the least pathogenic.

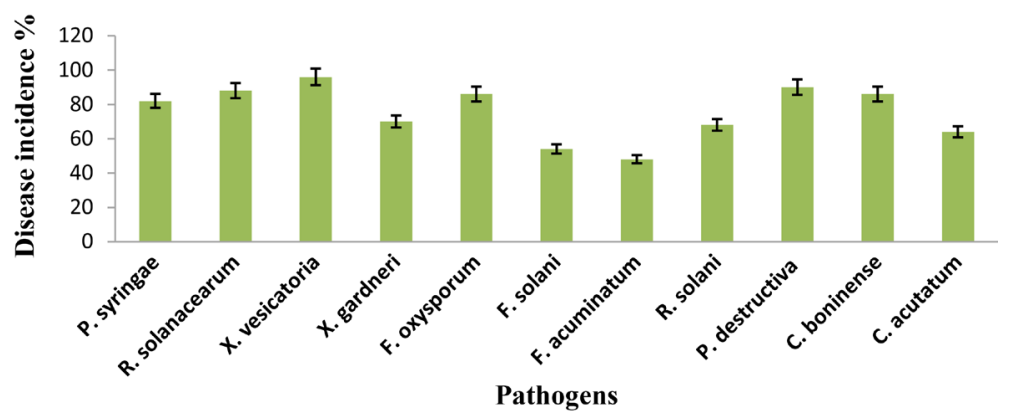

Figure 3. Percentage of disease incidences of bacterial and fungal isolates.

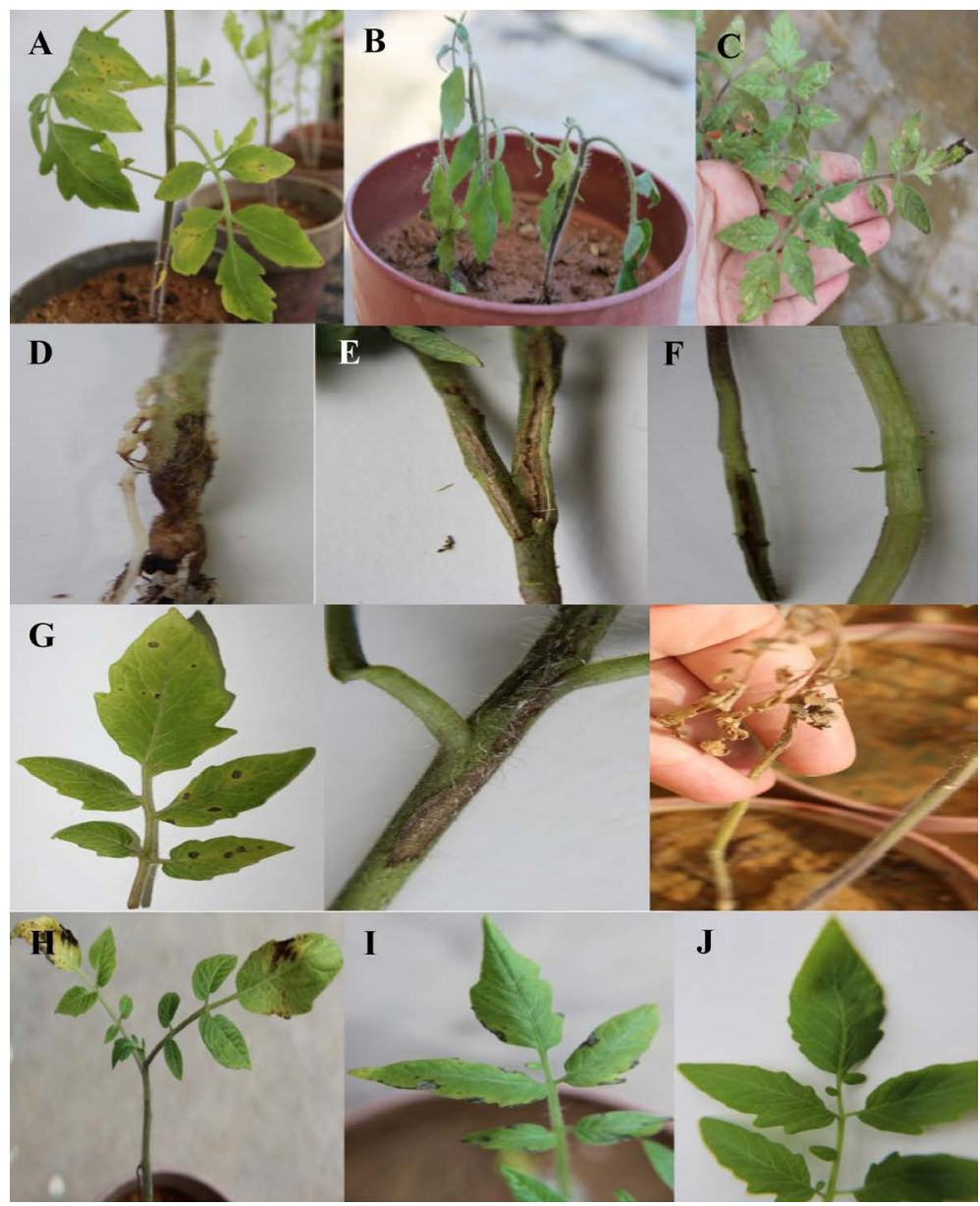

Figure 4. Different symptoms induced by different bacteria and fungi at 2 weeks after inoculation. (A) P. syringae, (B) R. solanacearum, (C) X. vesicatoria, (D) R. solani, (E) F. oxysporum, (F) F. solani, (G) P. destuctiva, (H) C. boninense, (I) C. acutatum and (J) Control. 
Re-isolation of the putative fungal and bacterial pathogens was carried out to fulfil Koch's postulates. Colonies that appeared were confirmed to have similar fungal and bacterial morphological characteristics.

\section{Discussion}

A total of 28 different fungal and 42 bacterial isolates were obtained from 60 samples collected from symptomatic tomato plants at Cameron Highlands, Pahang, Malaysia in this study. Four different bacteria and seven different fungi isolates were identified by molecular techniques to confirm the pathogens. All the selected isolates were pathogenic to tomato plants as confirmed by pathogenicity tests.

The pathogenicity test revealed that the $F$. solani and $F$. acuminatum were the least pathogenic to tomato plants as compared to $F$. oxysporum under test conditions even though the Fusarium species were commonly found in tomato plantations. Nevertheless, they still remain a possible risk as some of them still caused symptoms. While causing rot on tomato fruits, F. acuminatum was found to be a weak pathogen on tomato seedlings in the present study and these results compare well with the findings of Soekarno and Marhaenis [13].

Chlorosis, leaf wilting and browning of the vascular system were the usual symptoms apparent on inoculated seedlings with $F$. oxysporum. These symptoms were similar to those described byBenhamou et al. [14] and Ignjatov et al. [15]. Kashif [16] demonstrated that the early symptom was clearing of the ultimate veinlets in the leaflets of infected tomatoes, giving them a "netted" appearance. It could only be seen when viewed with transmitted light. These symptoms were reported byJones et al. [17] and Ibrahim [18] to often occur on mature plants after flowering and at the beginning of fruit setting.

Taproots with reddish brown cortical lesions and vascular discoloration above and below the lesions are symptoms of $F$. solani Benhamou and Thériault [19] also mentioned that $F$. solani caused the same symptoms.

Wani [20] has reported that the rots caused by $P$. destructiva are among the most potent diseases faced by tomato plants. Tomato plants were also found to be very vulnerable to $P$. destructiva. This was shown in the pathogenicity tests, which indicated that the most severe disease was caused by $P$. destructiva on tomato seedlings. Similar symptoms with our pathogenicity results were also reported by Wani [20] and Rashid et al. [21].

$R$. solani triggered stem cankers on the inoculated tomato plants. Montealegre et al. [22] described similar symptoms caused by $R$. solani where infected mature tomato plants had their roots turn brown and die after a period of time.

We only managed to isolate $C$. boninense and $C$. acutatum even though researchers have reported that $C$. coccodes and C. gloeosporoides were the major fungal causes of anthracnose on tomatoes [23]-[25]. C. boninense's symptoms included circular and immersed lesions with orange spore masses in a dark centre, which turn the infected leaves black after three weeks [26].

When plants inoculated with $P$. syringae pv. tomato, the leaves showed black necrotic specks encircled by yellow coronas and the fruits had dark brown to black surface abrasions with a diameter of approximately $2 \mathrm{~mm}$. These symptoms were similar to those mentioned by Louws et al. [27], Zhao et al. [28] and Ji et al. [29]. Other researchers described brown black leaf spots sometimes surrounded by chlorotic margin, dark superficial specks on green fruit and specks on ripe fruit that may become sunken and surrounded by a zone of delayed ripening. If young plants were infected, it would result in stunting and yield loss [30].

Tomato plants exposed to $R$. solanacearum had wilted on foliar with no foliar yellowing. Whitish ooze was evident when the affected plants' cut stems were submerged in water and the longitudinal sections had brown discolouration. These similar symptoms were also mentioned by Huangand Allen [31] and Pradhanang et al. [32].

$X$. vesicatoria caused the leaves to have small circular dark brown spots, which were water-soaked, and approximately $3 \mathrm{~mm}$ in diameter. The same symptoms were also mentioned by Jones et al. [33], Cavalcanti et al. [34] and Kocal et al. [35]. Similar symptoms were also observed when tomato seedlings were inoculated with $X$. gardneri, as were reported by Ma et al. [36], Quezado-Duval et al. [37] and Rashid et al. [38]. Previous studies indicated that $R$. solanacearum and $X$. vesicatoria were related to tomato infections in Malaysia [39].

\section{Conclusions}

Different tomato plant pathogens were collected from various tomato fields in Cameron Highlands, Pahang, Malaysia. Pathogenicity analysis showed that most of the fungi and bacteria isolates were pathogenic towards tomato plants. The pathogen inoculated plants exhibited typical disease symptoms after one week, while un-ino- 
culated plants were without such symptoms.

Most of the isolated bacteria and fungi were pathogenic to tomato plants however, $X$. vesicatoria, $R$. solanacearum, $C$. boninense, $P$. destructiva and $F$. oxysporum were the most virulence isolates. $C$. boninense, $P$. destructiva and $P$. syringae pv. tomato were the first reported in Malaysia.

\section{Acknowledgements}

This study was supported financially by University Putra Malaysia (grant No 9438737).

\section{References}

[1] Wang, Y.T., Liu, R.L., Huang, S.W. and Jin, J.Y. (2009) Effects of Potassium Application on Flavor Compounds of Cherry Tomato Fruits. Journal of Plant Nutrition, 32, 1451-1468. http://dx.doi.org/10.1080/01904160903092663

[2] Ru, S., Chen, X., Wang, H., Ning, G. and Zhao, P. (2001) Study on the Biological Characteristics of Fulviafulva (Cooke) Ciferri. Acta Agriculturae Zhejiangensis, 14, 38-41.

[3] Allen, C., Prior, P. and Hayward, A.C. (2005) Bacterial wilt Disease and the Ralstonia solanacearum Species Complex. American Phytopathological Society, 510 p.

[4] Abdullah, H. (1992) Bacterial Wilt in Malaysia: Hosts, Disease Incidence and Geographical Distribution. Bacterial Wilt. ACIAR Proceeding No. 45, 334-337.

[5] Mahir, A.M., Diong, K.S. and Ismail, A. (1992) Virulence Studies of Pseudomonas solanacearum and Inheritance of Resistant in Lycopersicon esculentum. Bacteria Wilt. ACIAR Proceeding No. 45, 154-157.

[6] Davis, R.M., Nunez, J.J. and Subbarao, K.V. (1997) Benefits of Cotton Seed Treatments for the Control of Seedling Diseases in Relation to Inoculum Densities of Pythium Species and Rhizoctonia solani. Plant Disease, 81,766-768. http://dx.doi.org/10.1094/PDIS.1997.81.7.766

[7] Kleemann, R., Zadelaar, S. and Kooistra, T. (2008) Cytokines and Atherosclerosis: A Comprehensive Review of Studies in Mice. Cardiovascular Research. http://dx.doi.org/10.1093/cvr/cvn120

[8] Daghman, I.M., Sariah, M., Kadir, J., Zainal-Abidin, M.A. and Rosenani, A.B. (2006) Dry Preparation of Trichoderma harzianum for Controlling Rhizoctonia Damping-Off in Brassica rapa. International Journal of Agricultural Research, 1, 590-596. http://dx.doi.org/10.3923/ijar.2006.590.596

[9] Gonzalez-Mendoza, D., Argumedo-Delira, R., Morales-Trejo, A., Pulido-Herrera, A., Cervantes-Díaz, L., Grimaldo-Juarez, O. and Alarcón, A. (2010) A Rapid Method for Isolation of Total DNA from Pathogenic Filamentous Plant Fungi. Genetics and Molecular Research, 9, 162-166. http://dx.doi.org/10.4238/vol9-1gmr680

[10] White, T.J., Bruns, T., Lee, S. and Taylor, J. (1990) Amplification and Direct Sequencing of Fungal Ribosomal RNA Genes for Phylogenetics. In: Innis, M.A., Gelfand, D.H., Sninsky, J.J. and White, T.J., Eds., PCR Protocols: A guide to Methods and Applications, Academic Press, San Diego, U.S.A, 315-322. http://dx.doi.org/10.1016/b978-0-12-372180-8.50042-1

[11] Rashid, T.S., Sijam, K., Kadir, J., Saud, H.M., Awla, H.K., Zulperi, D. and Hata, E.M. (2016) Screening for Active Compounds in Rhus coriaria L. Crude Extract That Inhibit the Growth of Pseudomonas syringae and Ralstonia solanacearum. Indian Journal of Agricultural Research, 50, 15-21. http://dx.doi.org/10.18805/ijare.v50i1.8583

[12] Latha, P., Anand, T., Ragupathi, N., Prakasam, V. and Samiyappan, R. (2009) Antimicrobial Activity of Plant Extracts and Induction of Systemic Resistance in Tomato Plants by Mixtures of PGPR Strains and Zimmu Leaf Extract against Alternaria solani. Biological Control, 50, 85-93. http://dx.doi.org/10.1016/j.biocontrol.2009.03.002

[13] Soekarno, B.P.W. and Marhaenis, E. (2013) Potensi Ekstrak Kangkung Sebagai Biofungisida Untuk Mengendalikan Penyakit Busuk Buah Fusarium PadaTomat. Jurnal Fitopatologi Indonesia, 8, 121-127.

[14] Benhamou, N., Lafontaine, P.J. and Nicole, M. (1994) Induction of Systemic Resistance to Fusarium Crown and Root Rot in Tomato Plants by Seed Treatment with Chitosan. Phytopathology, 84, 1432-1444. http://dx.doi.org/10.1094/Phyto-84-1432

[15] Ignjatov, M., Milošević, D., Nikolić, Z., Gvozdanović-Varga, J., Jovičić, D. and Zdjelar, G. (2012) Fusarium oxysporum as Causal Agent of Tomato Wilt and Fruit Rot. Pesticidii Fitomedicina, 27, 25-31.

[16] Kashif, Y.M.O.A. (2015) Survey and Identification of Fungal Diseases of Import Ant Crops in the White Nile State. Doctoral Dissertation, UOFK.

[17] Jones, J.B., Jones. J.P., Stall, R.E. and Zitter, T.A. (1991) Compendium of Tomato Disease. American Phytopathological Society Press, St. Paul, 73.

[18] Ibrahim, A.M.A. (2015) Investigations on Fusarium oxysporum f. sp. lycopersici the Casual Agent of Tomato Wilt (Lycopersicon esculentum Mill). Doctoral Dissertation, UOFK. 
[19] Benhamou, N. and Thériault, G. (1992) Treatment with Chitosan Enhances Resistance of Tomato Plants to the Crown and Root Rot Pathogen Fusarium oxysporum f. sp. Radicis-Lycopersici. Physiological and Molecular Plant Pathology, 41, 33-52. http://dx.doi.org/10.1016/0885-5765(92)90047-Y

[20] Wani, A.H. (2011) An Overview of the Fungal Rot of Tomato. Mycopath, 9, 33-38.

[21] Rashid, T.S., Sijam, K., Nasehi, A., Kadir, J., Saud, H.M. and Awla, H.K. (2016) Occurrence of Phoma Blight Caused by Phoma destructiva on Tomato (Solanum lycopersicum) in Malaysia. Plant Disease, Published Online.

[22] Montealegre, J.R., Reyes, R., Pérez, L.M., Herrera, R., Silva, P. and Besoain, X. (2003) Selection of Bioantagonistic Bacteria to Be Used in Biological Control of Rhizoctonia solani in Tomato. Electronic Journal of Biotechnology, 6, 115-127. http://dx.doi.org/10.2225/vol6-issue2-fulltext-8

[23] Byrne, J.M., Hausbeck, M.K. and Latin, R.X. (1997) Efficacy and Economics of Management Strategies to Control Anthracnose Fruit Rot in Processing Tomatoes in the Midwest. Plant Disease, 81, 1167-1172. http://dx.doi.org/10.1094/PDIS.1997.81.10.1167

[24] Dillard, H.R. and Cobb, A.C. (1998) Survival of Colletotrichum coccodes in Infected Tomato Tissue and in Soil. Plant Disease, 82, 235-238. http://dx.doi.org/10.1094/PDIS.1998.82.2.235

[25] Gautam, A.K. (2014) The Genera Colletotrichum: An Incitant of Numerous New Plant Diseases in India. Journal on New Biological Reports, 3, 9-21.

[26] Rashid, T.S., Sijam, K., Kadir, J., Saud, H.M., Awla, H.K. and Hata, E.M. (2015) First Report of Tomato Anthracnose Caused by Colletotrichum Boninense in Malaysia. Journal of Plant Pathology, 97, 216.

[27] Louws, F.J., Wilson, M., Campbell, H.L., Cuppels, D.A., Jones, J.B., Shoemaker, P.B., Miller, S.A., et al. (2001) Field Control of Bacterial Spot and Bacterial Speck of Tomato Using a Plant Activator. Plant Disease, 85, 481-488. http://dx.doi.org/10.1094/PDIS.2001.85.5.481

[28] Zhao, Y., Thilmony, R., Bender, C.L., Schaller, A., He, S.Y. and Howe, G.A. (2003) Virulence Systems of Pseudomonas syringae pv. Tomato Promote Bacterial Speck Disease in Tomato by Targeting the Jasmonate Signaling Pathway. The Plant Journal, 36, 485-499. http://dx.doi.org/10.1046/j.1365-313X.2003.01895.x

[29] Ji, P., Campbell, H.L., Kloepper, J.W., Jones, J.B., Suslow, T.V. and Wilson, M. (2006) Integrated Biological Control of Bacterial Speck and Spot of Tomato under Field Conditions Using Foliar Biological Control Agents and Plant Growth-Promoting Rhizobacteria. Biological Control, 36, 358-367. http://dx.doi.org/10.1016/j.biocontrol.2005.09.003

[30] Preston, G.M. (2000) Pseudomonas syringae pv Tomato: The Right Pathogen, of the Right Plant, at the Right Time. Molecular Plant Pathology, 1, 263-275. http://dx.doi.org/10.1046/j.1364-3703.2000.00036.x

[31] Huang, Q. and Allen, C. (2000) Polygalacturonases Are Required for Rapid Colonization and Full Virulence of Ralstonia solanacearum on Tomato Plants. Physiological and Molecular Plant Pathology, 57, 77-83. http://dx.doi.org/10.1006/pmpp.2000.0283

[32] Pradhanang, P.M., Momol, M.T., Olson, S.M. and Jones, J.B. (2003) Effects of Plant Essential Oils on Ralstonia solanacearum Population Density and Bacterial Wilt Incidence in Tomato. Plant Disease, 87, 423-427. http://dx.doi.org/10.1094/PDIS.2003.87.4.423

[33] Jones, J.B., Bouzar, H., Stall, R.E., Almira, E.C., Roberts, P.D., Bowen, B.W., Chun, J., et al. (2000) Systematic Analysis of Xanthomonads (Xanthomonas spp.) Associated with Pepper and Tomato Lesions. International Journal of Systematic and Evolutionary Microbiology, 50, 1211-1219. http://dx.doi.org/10.1099/00207713-50-3-1211

[34] Cavalcanti, F.R., Resende, M.L.V., Carvalho, C.P.S., Silveira, J.A.G. and Oliveira, J.T.A. (2006) Induced Defence Responses and Protective Effects on Tomato against Xanthomonas vesicatoria by an Aqueous Extract from Solanum lycocarpum Infected with Crinipellis perniciosa. Biological Control, 39, 408-417. http://dx.doi.org/10.1016/j.biocontrol.2006.05.009

[35] Kocal, N., Sonnewald, U. and Sonnewald, S. (2008) Cell Wall-Bound Invertase Limits Sucrose Export and Is Involved in Symptom Development and Inhibition of Photosynthesis during Compatible Interaction between Tomato and Xanthomonas campestris pv vesicatoria. Plant Physiology, 148, 1523-1536. http://dx.doi.org/10.1104/pp.108.127977

[36] Ma, X., Ivey, M.L. and Miller, S.A. (2013) First Report of Xanthomonas gardneri Causing Bacterial Spot of Tomato in Ohio and Michigan. Annual Review of Phytopathology, 51, 383-406.

[37] Quezado-Duval, A.M., Leite Jr, R.P., Truffi, D. and Camargo, L.E. (2004) Outbreaks of Bacterial Spot Caused by Xanthomonas gardneri on Processing Tomato in Central-West Brazil. Plant Disease, 88, 157-161. http://dx.doi.org/10.1094/PDIS.2004.88.2.157

[38] Rashid, T.S., Kamaruzaman, S., Golkhandan, E., Nasehi, A. and Awla, H.K. (2015) First Report of Xanthomonas gardneri Causing Bacterial Spot of Tomato in Malaysia. Plant Disease, 100, 854.

[39] Grimault, V., Schmit, J. and Prior, P. (1993) Some Characteristics Involved in Bacterial Wilt (Pseudomonas solanacearum) Resistance in Tomato. ACIAR Proceedings, No. 45, 112-119. 